\title{
Pesantren dan Perguruan Tinggi Agama Islam Menghadapi Liberalisasi Pendidikan
}

\author{
Ainurrafiq Dawam
}

Since 1994, liberation of education has been rolled in Indonesia. Government of Indonesia has been ratified liberation of education with UU No. 47, 1994. Indonesia has to implement it on all guidelines of national education. Free from positive or negative effect, Indonesian govemment and citizen have to realize the significant and the urgent of liberation of education. Part of institution of education in Indonesia are Pesantren and PTAI (Islamic university). This article would like to discuss shortly about readiness of pesantren and PTAI (Islamic university) to commemorate liberation of education.

Kata kunci: pesantren, PTAI, liberalisasi pendidikan

iberalisasi pendidikan telah mulai digulirkan di indonesia sejak tahun 1994. Pemerintah Indonesia telah meratifikasi liberalisasi pendidikan dengan disahkannya UU No. 47, tahun 1994. Dengan adanya undang-undang ini, sebagai negara hukumtentunya harus taat kepada hukum, Negara Indonesia harus mengimplementasikan dalam berbagai kebijakan pendidikan nasionalnya. Terlepas dari dampak positif dan negatif yang muncul, pemerintah Indonesia dan masyarakat harus siap melaksanakan liberalisasi pendidikan. Jika tidak melaksanakannya, maka dikhawatirkan Negara Indonesia mendapat sanksi berupa dikeluarkan dari anggota World Trade Organization (WTO).

Di antara sebagian dari berbagai institusi pendidikan di Indonesia yang juga harus menghadapi liberalisasi pendidikan adalah pesantren dan Perguruan Tinggi Agama Islam (PTAI). Pesantren bagi masyarakat Indonesia, khususnya umat Islam, dianggap sebagai institusi pendidikan Islam yang paling. tua (untuk tidak mengatakan yang pertama kali dalam sejarah). ${ }^{1}$ [1] Sampai tahun 2004 jumlah pesantren mencapai 14.656 buah. $^{2}$ [2] Sebagai sebuah institusi pendidikan yang telah eksis sejak lama dan sampai sekarang ini masih eksis, bahkan pernah dijadikan sebagai model instistusi pendidikan yang lain, tentu pesantren secara inheren memiliki kelebihan khusus dalam menghadapi berbagai perubahan masyarakat maupun berbagai perkembangan yang ada. Sedangkan, PTAl merupakan sebuah lembaga pendidikan Islam yang datang paling belakang. PTAl oleh masyarakat muslim Indonesia dianggap sebagai lembaga pendidikan yang tertinggi, karena di atas PTA tidak ada lagi lembaga pendidikan Islam. 


\section{Nilai Dasar Pesantren}

Eksistensi pesantren sejak zaman prakolonialisme sampai sekarang ini telah membuktikan bahwa di dalamnya terdapat nilai-nilai luhur yang sangat mendasar. Nilainilai luhur yang mendasar, oleh para pengelola pesantren senantiasa diimplementasikan dalam selunuh aspek kepesantrenan mulai dari manajemen, kultur, profesi, interaksi, sampai pada pola transmisi ajaran Islam. Nilai-nilai dasar inilah yang menjadi kekuatan utama pesantren di Indonesia dalam menghadapi berbagai gelombang perubahan masyarakat dan dunia sekitarnya. Tanpa kesetiaan terhadap nilai-nilai dasar ini rasanya tidak mungkin pesantren sampai saat ini tetap eksis, meskipun oleh sebagian pihak dianggap sebagai institusi yang melestarikan tradisionalitas masyarakat marginal.

Di antara nilai-nilai dasar yang ada dalam pesantren adalah:

\section{Orientasi Transendental}

Para ulama pesantren, khususnya pendiri dan perintis sebuah pesantren memiliki orientasi yang sangat mulia, yakni pengabdian kepada Allah SWT dalam upaya menggapai ridla-Nya ('ibadullah li ibtigha' mardlatillah).3 [3] Orientasi yang demikian, biasa disebut juga dengan istilah orientasi transendental. Orientasi yang demikian, tidak akan pernah ada dalam diri seorang pegawai negeri atau karyawan sebuah perusahaan. Para uiama ini hanya mengharapkan balasan yang setimpal dari Allah SWT dalam menjalankan roda kehidupan pesantren. Kekayaan yang mereka miliki misalnya tanah, perhiasan, dan uang semuanya dibelanjakan untuk suksesnya perjalanan pesantren. Perjaianan pesantren itu sendiri pada intinya adalah terselenggaranya proses belajar mengajar ajaran Islam dari sang ulama kepada para santrinya. Berbeda dengan orientasi pegawai negeri, meskipun di antara mereka ada yang berpendapat bahwa pekerjaan ini juga hanya karena Allah SWT, akan tetapi nilai-nilai yang terkandung dalam pekerjaan itu sendiri jelas berbeda.

Perbedaan ini dapat dilihat dari input, proses, maupun outputnya. Input kyai dalam pesantren adalah bekal ilmu yang dimiliki dan modal yang ada dalam dirinya tanpa adanya keterkaitan dengan pihak lain. Kalaupun terdapat keterkaitan dengan pihak lain bukaniah dalam arti ketergantungan yang sangat tinggi. Sedangkan input pegawai negeri bukan hanya bekal ilmu yang dimiliki, akan tetapi tergantung pada beberapa hal, seperti kesesuaian keahlian yang dimiliki dengan formasi yang dibutuhkan, adanya koneksi tertentu dengan atasan, adanya kesesuaian ideologi dengan lembaga yang menyediakan pekerjaan, dan tentunya modal khusus yang sudah menjadi rahasia umum dalam bentuk biaya syukuran, biaya kelancaran, biaya administrasi atau lainnya. Model input yang demikian ini juga tidak jauh berbeda dengan karyawan dalam sebuah perusahaan. Proses yang ada dalam pesantren hanya dilaksanakan sebagai sarana untuk menggapai orientasi transendental. Proses belajar mengajar yang dilaksanakan wajib dan hanya untuk melestarikan ajaran Islam. Sedangkan pengembangan ajaran Islam dilakukan dengan sangat hati-hati agar tidak sampai terjerumus atau terlempar ke jurang kesesatan yang sangat dijauhi para ulama. Hal ini jelas berbeda dengan proses yang terjadi pada pegawai negeri. Untuk pegawai negeri proses pekerjaan yang dilakukan hanya untuk kepentingan dirinya sendiri, bukan untuk melestarikan ajaran Islam. Bahkan kadang-kadang pekerjaan yang berupa layanan kepada masyarakat dilakukan dengan perasaan terpaksa, 
sehingga slogan "kalau bisa dipersulit kenapa harus dipermudah" menjadi sangat dekat dengan proses pekerjaan pegawai. Mungkin hal ini berbeda dengan karyawan sebuah perusahaan, artinya karyawan dalam melaksanakan proses pekerjaan dilakukan dengan sungguh-sungguh, hanya saja semua itu dimaksudkan untuk kepentingan dirinya sendiri. Dalam hal output kyai pesantren hanya mengharpkan para santrinya bisa menjadi manusia yang saleh berakhalkul karimah dan senantiasa menyebarkan ajaran yang telah diperoleh di tempat belajar. Kyai tidak mengharapkan balasan yang setimpal dari para santrinya dalam bentuk materi, karena dengan berhasilnya santri dalam menyebarkan ajaran Islam ke seluruh penjuru tanah air sudah menjadi kebanggan yang, luar biasa baginya. Hal ini berbeda dengan outputyang diharapkan dari pegawai negeri yang tidak lain adalah imbalan yang berupa materi yakni pangkat dan golongan yang tinggi yang ujung-ujungnya adalah penerimaan gaji yang besar. Yang demikian ini juga berlaku bagi karyawan sebuah perusahaan, outputnya tidak lain adalah upah kerja yang besar sebagai.imbalan terhadap kinerja yang telah dilakukannya.

Dari sini dapat dilihat bagaimana orientasi transendental menjadi orientasi puncak bagi para ulama dalam merintis dan mendirikan pesantren. Orientasi yang demikian ini tidak akan pernah lapuk oleh perubahan zaman dan perkembangan masyarakat dalam bentuk apapun. Perubahan dan perkembangan masyarakat bukanlah menjadi pemghalang bagi para ulama dalam merintis dan mendirikan pesantren. Justru perubahan dan perkembangan masyarakat menjadi tantangan yang tiada habis bagi para ulama dalam rangka jihad fi sabilillah yakni menyebarkan ajaran Islam di manapun mereka berada, tentunya dengan tidak merugikan pihak-pihak yang lain.

\section{Transmisi Ajaran Islam adalah Kewajiban}

Nilai dasar pesantren yang kedua ini merupakan kesadaran yang harus ada dalam setiap pengelola pesantren. Transmisi ajaran Islam bukaniah sebuah pekerjaan yang sia-sia, akan tetapi merupakan kewajiban yang benar-benar disadari oleh para ulama dan kyai.4 [4] Tanpa kesadaran ini para ulama tidak akan pernah eksis sampai saat ini. Transmiși ajaran Islam bisa dilakukan dengan berbagai cara. Namun bagi para ulama, pesantren adalah sarana yang paling tepat untuk melaksanakan kewajiban ini. Hal ini didasarkan pada beberapa alasan yakni: Pertama, pesantren tidak akan pernah terlepas dari transmisi ajaran Islam yang meliputi pemikiran, ucapan, dan perilaku. Dalam sebuah pesantren ketiga kegiatan transmisi ini dilaksanakan secara nonstop selama 24 jam. Ketika sebuah pesantren tidak melaksanakan transmisi dalam tiga bentuk selama 24 jam penuh, maka pesantren tersebut perlu dipertanyakan orientasinya. Transmisi pemikiran dilaksanakan melalui pengkajian kitab-kitab klasik (kitab kuning) dengan kontekstualisai tema yang sedang dikaji. Transmisi ucapan dilaksanakan dalam bentuk dialog dan pelafalan ayat-ayat ai-Qur'an atau ajaran Islam dalam berbagai aktivitas seperti mengaji, shalat (baik maktubah maupun yang sunnah), dan berinteraksi dengan masyarakat. Sedangkan transmisi dalam bentuk tindakan dilaksanakan dalam berbagai kegiatan amaliah ibadah maupun muamalah baik secara internal (dalam pesantren) maupun secara eksternal (masyarakat, negara, bahkan dunia global). Kedua, kehidupan di pesantren merupakan model 
Topik: Globalisasi dan Liberalisasi dalam Bidang Pendidikan

kehidupan yang sangat kondusif bahkan konstruktif bagi transmisi ajaran Islam. Transmisi ajaran Islam dapat dilakukan dengan baik ketika sarana, situasi, kondisi, dan. lingkungan sangat mendukung. Pesantren dalam berbagai aktivitas yang direncanakan semua diarahkan untuk mendukung terjadinya transmisi ajaran islam. Mulai dari bangun tidur sampai menjelang tidur, semuanya diarahkan untuk menyampaikan ajaran Islam secara komprehensif. Kondusivitas dan konstruksivitas ini sangat tergantung pada model dan pola kehidupan pesantren. Peśantren yang hanya mengadopsi dari sisi manajemen belum tentu mampu mengadaptasikan kultur yang ada dalam pesantren. Dalam hal ini yang paling dominan memang kultur pesantren yang sangat khas. Dalam istilah Abdurrahman Wahid pesantren sebagai subkultur yang unik.5 [5] Jika kekhasan ini kemudian dikurangi satu saja, maka kultur yang ada sudah tidak kondusif lagi. Ketiga, dialog kultural yang dilakukan pesantren dengan masyarakat sangat mendukung transmisi ajaran Islam kepada mereka. Adopsi pesantren terhadap nilai-nilai kultur yang ada dalam masyarakat merupakan prestasi yang luar biasa baginya. Institusi selain pesantren bukannya untuk mengadopsi dan melestarikan kultur masyarakat yang ada, akan tetapi berusaha untuk merubah atau bahkan mendekonstruksi kultur masyarakat yang sudah ada dengan dalih mengikuti kemajuan global. Pesantren dalam - mensikapi kemajuan global senantiasa didasarkanm pada nilai-nilai tradisi kultur masyarakat yang sudah ada. Dengan demikian, masyarakat tidak akan mengalami goncangan budaya (shock culture) terhadap' eksistensi dan perkembangan pesantren. Bahkan pesantren menjadi salah satu icon bagi proses akulturasi dan adaptasi kemajuan global yang paling fleksibel dan taat prinsip masyarakat yang sudah ada.

Transmisi ajaran Islam melalui pesantren menjadi salah satu prioritas utama para kyai mengingat semakin jauhnya institusi transmisi ajaran Islam yang lain dari kultur masyarakat yang sudah ada, bahkan bertolak belakang. Atas dasar inilah kewajiban transmisi ajaran Islam yang menjadi kesadaran utama para ulama harus dilaksanakan dalam sebuah pesantren. Kewajiban transmisi ajaran islam bagi alumni pesantren merupakan puncak prestasi yang harus dicapainya. Jangan sekali-kali menganggap dirinya seorang santri jika tidak mampu atau bahkan tidak mau menjadikannya sebagai ultimate goal dalam kehidupan pasca "menyantri" di pesantren.

\section{Kesederhanaan sebagai Implementasi Ketaqwaan}

Kesederhanaan menjadi nilai dasar pesantren, karena dengan sikap inilah kecemburuan sosial yang bersifat material bisa dikikis habis. Kesederhanaan di sini meliputi kesederhanaan dalam pola hidup, pola pikir, pola perasaan, pola perilaku. Kesederhanaan bukan berarti seorang ulama pesantrẹn dilarang keras untuk menjadi jutawan atau bahkan miliarder, melainkan sikap untuk tidak membanggabanggakan segala yang dimiliki di hadapan orang lain. Atau sebaliknya, artinya menjadikan bekal ilmu yang dimiliki sebagai senjata pamungkas untuk memperkaya diri, men-"terkenalkan diri," dan mem-"perkuasakan diri" dengan cara-cara yang bertolak belakang dengan ajaran Islam yang selama ini diterimanya ketika di pesantren.

Kecenderungan kearah kesederhanaan semakin mendekatkan seseorang atau 
sekelompok orang kepada rasa solidaritas kemanusiaan. Solidaritas kemanusiaan yang didukung semua pihak tidak akan pernah terlaksana, manakala setiap individu yang ada dalam masyarakat tidak memiliki keinginan untuk mempraktikkan kesederhanaan. Siapapun tahu bahwa pemenuhan hawa nafsu tidak akan pernah selesai, meskipun semua keinginan yang dimiliki pada saat itu sudah terpenuhi semua. Pada suatu saat dia akan mencari pemenuhan untuk keinginan yang berbeda. Perubahan keinginan ini selalu terjadi dalam hitungan hari, jam, menit, bahkan detik. Artinya setiap detik keinginan yang muncul dalam diri seseorang senantiasa tumbuh dan berbeda dari keinginan yang sudah ada. Ketika pemenuhan hawa nafsu sudah tidak mungkin untuk dipenuhi secara paripurna, maka pada saat itulah sikap kesederhanaan menjadi muara yang paling tepat, agar seseorang tidak terus menerus dalam kondisi tertekan. Seiring dengan kesederhanaan yang ada dalam diri seseorang, rasa kesetiakawanan sebagai sesama manusia akan muncul. Kelebihan yang ada pada dirinya, akan menjadi sangat bernilai tinggi dan besar jika diberikan atau diserahkan kepada orang yang sangat membutuhkan. Munculnya rasa solidaritas yang demikian inilah yang menjadi acuan utama para ulama di pesantren dalam mengajarkan dan mempraktikkan sikap kesederhanaan. Dengan adanya pewarisan sikap yang demikian kepada banyak pihak (para santri), diharapkan solidaritas sesama manusia bukan hanya menjadi "isapan jempol" belaka, sebagaimana yang biasa dapat dilihat dalam era kontemporer ini yang semakin banyak kepalsuan hidup.

Kesederhanaan dalam seluruh pola kehidupan manusia, bagi para ulama dijadikan sebagai bukti implementasi ketaqwaan kepada Allah SWT. Telah menjadai wacana umum, khususnya umat Islam bahwa taqwa adalah standar peringkat manusia di hadapan Aliah SWT. Ketika ketaqwaan telah terimplementasi dalam seluruh kehidupan seseorang, maka berbagai hambatan bahkan tantangan yang muncul baik dari masyarakat sendiri maupun masyarakat lain (dunia global) dapat dihadapi dengan seksama dan arif. Inilah yang menjadi cikal bakal kelestarian pesantren sampai dewasa ini. Pewarisan sikap kesederhanaan sebagai implementasi ketaqwaan menjadi nilai dasar yang harus ada dalam pesantren (wajib al-wujud fi altarbiyah al-Islamiyah).

\section{Keteguhan Memegang Prinsip Wasathan Islam}

Prinsip wasathan (moderat) menjadi nilai dasar pesantren yang sangat penting. Prinsip moderat ini menjadi nilai dasar yang harus ditransmisikan dalam proses belajar mengajar di pesantren. Prinsip moderat merupakan salah satu warisan para ulama yang paling penting. Dengan prinsip moderat ini, pesantren bagaimanapun sederhananya senantiasa mampu mengimbangi berbagai kemajuan yang ada. Prinsip moderat dipahami sebagai prinsip kehati-hatian pesantren dalam merespons berbagai isu kontemporer yang berhembus baik dari Barat maupun dari Timur. Hembusan isu kontemporer selalu didukung oleh sarana dan prasarana pendukung baik yang berbentuk software, hardware, maupun brainware. Pesantren dalam mensikapi berbagai isu kontemporer senantiasa mengedepankan prinsip moderat. Artinya tidak serta merta menolak atau menerima tanpa pertimbangan (taken for granted).

Para ulama pesantren dalam mewariskan prinsip moderat ini bukan hanya disampaikan secara lisan (bi al-qaul), akan tetapi juga dibuktikan dalam perilaku 
Topik: Globalisasi dan Liberalisasi dalam Bidang Pendidikan

keseharian (bi al-hal). Model pewarisan prinsip dengan menggunakan metode lisan dan perilaku merupakan model yang paling tepat. Dengan model pewarisan seperti ini para santri bisa secara langsung mendengarkan dan menyaksikan penyampaian sebuah prinsip. Berbeda dengan model penyampaian yang dilakukan secara lisan saja. Penyampaian secara lisan tentang sebuah prinsip hanya diingat ketika sedang diucapkan, tetapi setelah itu sangat rawan terhadap pengingkaran atau kelupaan. Oleh karena itu, sangat tepat ketika para ulama pesantren dalam menyampaikan prinsip wasathan ini dilakukan secara lisan dan dipraktikkan dalam perilaku kehidupannya.

Tantangan dan peluang yang diakibatkan munculnya isu-isu kontemporer dapat dihädapi dengan prinsip wasathan ini. Prinsip wasathan inilah yang menjadi andalan para ulama pesantren, sehingga pesantren sampai sekarang masih eksis bahkan telah meneiorkan tokoh-tokoh besar, khususnya di Indonesia. Isu-isu kontemporer yang muncul sebagai akibat dari kemajuan ilmu pengetahuan dan teknologi merupakan sebuah keniscayaan yang harus dihadapi pesantren. Isu-isu kontemporer tersebut bukan hanya dalam aras wacana, akan tetapi sudah merambah pada aras pelaksanaan. Untuk menghadapi isu-isu kontemporeryang benar-benar benar-benar telah dipraktikkan mau tidak mau harus dipersiapkan semua pihak, khususnya yang berkecimpung dalam pesantren.

Keteguhan dalam memegang prinsip moderat ini menjadi kekuatan yang dimiliki pesantren sehingga mampu eksis bahkan mewarnai lembaga pendidikan di Indonesia. Keteguhan tersebut dapat diwujudkan dengan kebijakan yang diambil para alumni pesantren yang bukan hanya mengekor kemajuan pihak lain. Kebijakan yang demikian ini tentunya menjadi ciri khas para santri, karena memang karakter yang dimilikinya adalah keteguhan dalam memegang prinsip. Meskipun seorang santri telah tercelup dengan tradisi atau kemajuan peradaban lain dia akan tetap memegang teguh prinsip moderat ini. Keteguhan tersebut juga dapat diwujudkan dalam bentuk perilaku yang tidak mudah mengikuti trend peradaban lain sebelum diteliti dan dilihat tradisi lama yang sudah ada. Setelah dipastikan bahwa trend baru tersebut tidak bertentangan dengan tradisi yang dimilikinya, maka dia akan mengikutinya dengan sangat hati-hati. Saking hati-hatinya seakan-akan dia tidak melakukan pembaharuan sama sekali, padahal tidak.

\section{Solidaritas Kemanusiaan yang Tinggi}

Solidaritas yang dalam bahasa agama sering dikenal dengan sebutan ukhuwah pada dasarnya menupakan naluri positif yang ada pada semua orang.7 [7] Manusia dengan berbagai suku bangsa yang berbeda dan tersebar di seluruh penjuru dunia ini pada hakikatnya memiliki rasa solidaritas. Jika ada seseorang yang mengaku tidak memiliki rasa solidaritas dalam jiwanya, maka dapat dikatakan dia telah kehilangan roh kehidupannya. Solidaritas yang tertinggi adalah solidaritas kemanusiaan. 8 [8] Solidaritas inilah yang menjadi nilai dasar dalam pesantren. Solidaritas di sini jangan dikontraskan dengan pengabdian kepada Allah SWT. Solidaritas di sini adalah pada level kemanusiaan yang tentunya didasari dengan ajaran ilahiyah. Solidaritas kemanusiaan sering diajarkan kepada para santri dengan melihat kedudukan manusia di antara syetan dan malaikat. Manusia lebih tinggi derajatnya dibanding dengan syetan karena syetan senantiasa durhaka kepada 
Allah SWT. Sedangkan manusia, meskipun ada kecenderungan untuk berbuat jahat, akan tetapi tetap memiliki sisi-sisi kebaikan. Dibandingkan dengan malaikatpun manusia lebih unggul derajatnya, karena meskipun malaikat senantiasa tunduk kepada Allah SWT, akan tetapi malaikat tidak memiliki hawa nafsu, sehingga tingkat ujiannya sama sekali tidak ada. Berbeda dengan manusia, meskipun tidak selalu beribadah kepada Allah SWT, akan tetapi manusia memiliki hawa nafsu yang cenderung pada keburukan. Dengan perjuangan untuk mengarahkan hawa nafsu pada hal-hal yang baik, manusia telah memiliki nilai perjuangan yang tentunya malaikat tidak memilikinya. Di sinilah nilai tertinggi manusi dibanding kedua makhluk Allah SWT tersebut. Oleh karena itu, solidaritas kemanusian dijadikan sebagai nilai dasar dalam pesantren merupakan keniscayaan yang sangat logis dan proporsional.

Para santri dalam memahami dan mempraktikkan rasa solidaritas kemanusiaan ini dilaksanakan secara berkesinambungan, mulai dari pendaftaran, pendadaran, silaturrahmi, aktivitas rutin, aktivitas insidental, sampai hubungan kultural dan struktural baik secara internal maupun eksternal. Pemahaman solidaritas yang demikian ini dilaksanakan dengan harapan agar para santri ketika menjadi seseorang yang berpengaruh tidak lantas melupakan dirinya sebagai manusia yang sederajat dengan manusia lainnya. Kesadaran kesetiakawanan kemanusiaan ini menduduki tingkat yang paling tinggi setelah solidaritas kehewanan dan kealaman. Artinya bahwa solidaritas kemanusiaan yang dilaksanakan para santri tidak serta merta menghalalkan segala cara dengan melakukan tindakan yang merusak dunia hewan maupun alam lingkungan sekitar. Pemahaman kesadaran solidaritas yang demikian ini menjadi sangat prinsipsbagi para santri. $\mathrm{Hal}$ ini dapat dilihat: dari kedekatan para ulama pesantren dan santri dengan alam lingkungan sekitar baik terhadap masyarakat, lingkungan sekitar, maupun makhluk hidup yang ada.

\section{Perguruan Tinggi Agama Islam: Pesantren Bernuansa Akademis}

Perguruan Tinggi Agama Islam (PTAI) menjadi andalan umat Islam di Indonesia dalam mewujudkan ilmu agama Islam sebagai rahmat bagi seluruh alam. PTAI yang sampai saat ini telah berjumlah ratusan (PTAIN 51 dan PTAIS 391)9 [9] dijadikan sebagai wahana pengembangan ilmu agama Islam. Di dalam PTAl diberikan materi kurikulum pendidikan yang tidak jauh berbeda dengan kurikulum pesantren dengan mengakomodasi ilmu-ilmu modern yang di pesantren tidak ada bahkan dilarang. Dengan demikian PTAI secara tidak langsung dapat dikatakan sebagai pesantren dengan nuansa akademik sebagaimana perguruan tinggi lain di Indo'nesia. Artinya bahwa PTAI merupakan institusi yang mempunyai dua fungsi dasar yakni lembaga dakwah dan lembaga akademis.

PTAl sebagai lembaga dakwah telah berlangsung sampai saat ini. Sebagai lembaga dakwah, maka komponen dakwah ada di alamnya. Mubalig sebagai penyampai materi dakwah (subyek dakwah) direpresentasikan oleh dosen dan pengelola PTAI. Audien sebagai orang yang diberi dakwah (obyek dakwah) dapat direpresentasikan oleh mahasiswa dan orang tuanya. Materi dakiwah direpresentasikan oleh kurikulum yang berupa matakuliah. Sedangkan strategi dakwah dapat direpresentsikan oleh metode pengajaran dan pembelejaran yang digunakan para dosen. Dari sini sangat jelas 
bariwa PTAI memiliki fungsi dakwah bagi kelangsungan ajaran agama Islam. Jadi, ketika sebuah PTAI sudah mengalami disfungsi sebagai lembaga dakwah, maka perguruan tinggi tersebut tidak berhak menyandang sebagai PTAl.

PTAl sebagai lembaga akademik dapat dilihat dari komponen yang telah ada. Sebuah lembaga dikatakan sebagai lembaga akademik, paling tidak harus memenuhi tiga keriteria utama, yakni terselenggaranya proses pendidikan can pengajaran, terselenggaranya penelitian dalam rangka pengembangan ilmu, dan terlaksananya pengabdian kepada masyarakat sebagai wujud kontribusi keilmuan. Semua PTAl yang ada di Indonesia jelas telah memenuhi tiga kriteria tersebut, meskipun dengan berbagai variasi dalam hal gradasi kualitasnya.

PTAl sejak awal keberadaannya dan akan selaiu memikul dua fungsi utama yakni lembaga dakwah dan lembaga akademik. Dwi fungsi ini tidak boleh hilang dalam diri PTAl. Ketika sebuah PTAI lebih mementingkan salah satu dari dua fungsi ini, maka umat Islam akan mengalami kekecewaan yang sangat besar. Kekecewaan ini sangat wajar mengingat beberapa alasan:

Pertama, PTAl sebagai lembaga Cákwah merupakan sarana yang sangat strategis. PTAl, bagaimanapun juga bagi masyarakat Muslim, telah diyakini sebagai lembaga pendidikan tertinggi yang mampu mengembangkan strategi dan model dakwah yang inovatif. Lembaga dakwah yang selama ini ada kesan bahwa dakwah dianggap cukup paripurna setelah acara sudah selesai. Padahal untuk melihat efisiensi dan efektivitas dakwah diperlukan pengamatan terhadap apa yang kemudian clipikirkan, apa yang kemudian diucapkan, dan apa yang kemudian dilaksanakan masyarakat. Berbeda dengan PTAl yang karena tugasnya harus mengamati bahkan meneliti apa yang terjadi sesudah dakwah dilaksanakan (ma ba'da al-da'wah). Oleh karena itu, sangat wajar bila umat Islam mengandalkan PTAl untuk menemukan inovasi konstruktif calam stratgei dan model dakwah yang harus dilakukan dengan memperhatikan perkembanjan msyarakat.

Kedua, PTAl sebagai lembaga akademik menupakan pusatpengkajian ilmu pengetahuan, tekrologi mutakhir, dan seni kontemporer. Untuk itu, PTAI harus menyediakan sarana dan prasaranayang mencukupi bagi terlaksananya bertagai penelitian dan pengembangan ilmu pengetahuan, teknologi, dan seni. Pengembangan ilmu pengetahuan, teknologi, dan seni merupakan implementasi dari kesadaran tertinggi akan pengabdian kepada Allah SWT. Dengan melihat realitas bahwa umat Islam senantiasa terpinggirkan dalam berbagai aspekkehidupan, maka PTAI diharapkan (baca: wajib) mampu memberikan jawaban kongkrit terhadap tantangan yang ada kepada umat islam. Harapan yang demikian ini, terasa sangat berat mengingat belum adanya dukungan optimal dari semua lapisan umat Islam sendiri. Sebagai sebuah lembaga akademik, PTAI hanya diorientasikan sebagai wahana pengembangan akademik bukan untuk ajang pertarungan politik yang tidak bermanfaat sama sekali.

Ketiga, PTAl sebagai lembaga dakwah dan lembaga akademik secara sinergis pernah terjadi dalam sejarah umat Islam. Pada masa keemasan Islam (abad 8-13 M) sinergisitas PTAI sebagai lembaga dakwah dan lembaga akademik terjaga sampai jangka waktu yang sangat panjang. Terjaganya sinergisitas di antara dua fungsi PTAl tersebut menjadikan Islam mampu memimpin peradaban dunia. Tidak 
bermaksud bernostalgia (sindrom romantik), realitas sejarah tersebut pernah digenggam umat Islam, salah satu pendukungnya adalah sinergisitas antara dua fungsi di atas dalam sebuah PTAI. Oleh karena itu, tidak terlalu naif manakala umat Islam sekarang mencoba untuk mengembalikan kondisi si atas dengan memberikan sumbangan sesuai dengan kemampuan yang dimilikinya. PTAI dengan fungsi akademik adalah sebagai pencetus ide-ide, ilmu-ilmu, teknologi-teknologi, dan seni terbaru sedangkan dengan fungsi dakwah adalah sebagai corong dan penyampai ajaran Islam haruslah menjadi orientasi utama para pemilik otoritas PTAI. Jika teiah mampu diwujudkan kondisi ideal semacam ini, maka dalam waktu yang tidak lama keunggulan Islam akan terbukti.

Dari sini dapat dikatakan bahwa PTAI berada pada posisi yang sangat strategis bagi umat Islam. PTAI, selain menjadi andalan bagi penyebaran dakwah Islam ke seluruh pelosok tanah air bahkan dunia, juga menjadi andalan bagi pengembangan ilmu agama Islam yang berguna bagi seluruh kehidupan masyarakat Muslim. Dari posisi yang strategis ini memunculkan keraguan atau pertanyaan, mungkinkah PTAI mampu menjadi lembaga dakwah yang andal sekaligus menjadi lembaga akademik yang unggul. Keraguan yang semacam ini sangat wajar jika muncul dalam diri setiap umat Islam yang masih memiliki rasa handarbeni terhadap PTAI. Untuk melihat hal ini perlu ditelisik lebih jauh bagaimana kekuatan internal dan dukungan eksternal PTAI.

Kekuatan internal PTAI sebenarnya dapat dilacak dari jati diri umat Islam, yaitu pengabdian kepada Allah SWT. Kekuatan ini merupakan kekuatan intemal yang sangat luar biasa, karena sejarah membuktikan bahwa kekuatan yang demikian ini menjadi pemicu awal bagi terselenggarăึya gebrakan-gebrakan strategis yangstuar biasa. Kesadaran dan kekuatan pengabdian kepada Allah SWT bagi seseorang yang telah mencapai tingkatan keimanan yang mantap akan menjadi motivasi yang luar biasa dalam melaksanakan berbagai kegiatan yang berkualitas. Mulai dari karya pikir, karya tulis, karya laku, dan karya kreasi. Bahkan tidak menutup kemungkinan muncul teknologi super canggih.

Dukungan eksternal mencakup dukungan finansial, moral, political will, dàn rasa memiliki (sense of belonging) dari masyarakat, khususnya masyarakat Muslim Indonesia. Dukungan finansial dapat direalisasiskan dalam bentuk pemberian sadaqah, infaq, wakaf, dan zakat. Dukungan moral bisa diwujudkan dalam bentuk sumbangan pemikiran baik berupa masukan maupun kritik demi perkembangan PTAI. Dukungan political will ini hanya dapat diberikan oleh umat Islam yang sedang berada pada posisi strategis dalam kekuasaan. Dukungan dalam bentuk rasa memiliki dapat dilakukan dengan menyerahkan pendidikan putera-puteri umat Islam kepada PTAI.

Keterpaduan antara kekuatan intemal dan eksternal di atas jika telah terbentuk secara sinergis, maka tidak perlu diragukan lagi PTAI akan mampu menghadapi berbagai tantangan dan hambatan baik dalam sekala kecil maupun besar. Keterpaduan akan terwujud manakala masing-masing pihak lebih mendahulukan kewajiban dari pada hak yang dimiliki. Selama ini yang muncul adalah menuntut hak lebih didahulukan dari pada memenuhi kewajiban yang harus dilaksanakan. Dengan pemahaman dan kesadaran akan kewajiban dan haknya dari masing-masing pihak ketercapaian tujuan PTAl akan dapat terwujud dengan lebih efektif. 
Untuk mendapatkan keterpaduan. antara kekuatan internal dan eksternal perlu dilakukan reorientasi PTAl, agar tidak terkesan ahistoris dengan meninggalkan cikal bakal dan keinginan para pendiri PTAI, namun tetap melihat dan memperhatikan perkembangan masyarakat yang terjadi baik di tingkat lokal, nasional, regional, bahkan global. Berpegang teguh terhadap apa yang telah menjadi orientasi utama para pendiri PTAI menjadi sangat penting mengingat telah banyak terjadi lembaga yang melupakan jati diri yang dimilikinya, sehingga mudah terhanyut ke daiam isu-isu kontemporer yang pada akhirnya tercerabut dari akar historisnya.

Kalau dilacak dari cikal bakal dan orientasi para pendirinya, sebenarnya PTAI tidak lain adalah pesantren dengan nuansa akademis dengan alasan bahwa PTAI tidak boleh menghilangkan salah satu dari dua fungsi utama yaitu fungsi dakwah dan fungsi akademis. Lembaga dakwah yang telah eksis sebelum Indonesia merdeka dan masih eksis sampai era informasi ini adalah pesantren. Oleh karena itu, dapat dikatakan bahwa lembaga dakwah yang tertua dan teruji eksistensinya adalah pesantren. Jika lembaga dakwah ini kemudian mengambil satu fingsi yang lain yaitu fungsi akademis, maka pesantren ini harus mengadopsi persyaratan minimal sebuah lembaga akademis, sebagaimana disebutkan di atas. Dengan demikian, PTAI dapat dikatakan sebagai pesantren tinggi yang bernuansa akademis.

Istilah pesantren masih dipertahankan mengingat nilai-nilai dasar yang dimilikinya merupakan kekuatan internal PTAl yang sangat besar dan tidak akan mampu digeser oleh apapun. Isu-isu kontemporer yang bertentangan dengan nilai-nilai dasar yang ada secara otomatis, cepat atau lambat, akan tertolak dengan sendirinya. Nilai-nilai dasar inilah yang menjadi inti kekuatan PTAI dan yang harus dipertahankan selamalamanya untuk menghindari pengkhianatan historis. Pengkhianatan terhadap historisitas PTAI merupakan kesalahan yang sangat besar yang tidak akan bisa diampunkan sejarah. Dari sini dapat dikatakan bahwa metafora PTAI dengan pesantren bernuansa akademis tidak lah berelebihan.

\section{Pesantren dan PTAI Siap Menghadapi Apapun, Termasuk Liberalisasi pendidikan}

Liberalisasi pendidikan telah menjadi isu global yang tidak lain adalah agenda negara-negara maju untuk menjadikan dunia ini menjadi satu sistem peradaban, satu model kehidupan, dan satu strategi pendidikan. Orientasi penyatuan dunia menjadi satu sistem, satu model, dan satu strategi telah dijadikan agenda utama negara-negara maju dengan slogan "New World Order" (tatanan dunia baru) dengan versi mereka. Prasyarat apapun yang dibutuhkan untuk meralisasikan tatanan dunia baru akan diperjuangkan dengan segala kekuatan dan pikiran yang dimiliki. Prasyarat untuk mewujudkan obsesi negaranegara maju tersebut meliputi seluruh bidang kehidupan, mulai dari ideologi, politik, ekonomi, sosial, budaya, bahkan agama.

Liberalisasi pendidikan merupakan jembatan emas bagi tersebarnya agendaagenda besar negara maju. Karena semua orang menyadari bahwa internalisasi ilmu, nilai, teknologi, dan seni sangat efektif bila dilaksanakan melalui proses pendidikan. Brainwashing akan terjadi dengan sangat mulus dan lancar. Otonomi lembaga pendidikan menjadi instrumen utama dalam memperlancar agenda di atas. Jika sebuah lembaga pendidikan telah diberi otonomi, maka apapun yang diinginkan oleh pendiri 
lembaga pendidikan tersebut akan terlaksana, sementara pemerintah tidak mampu mengakses ke dalam. Transmisi agenda, ideologi, nilai, dan kepentingan menjadi sangat lancar tanpa ada halangan sedikitpun, termasuk dari penguasa.

Liberalisasi pendidikan merupakan implementasi dari nilai kompetisi yang menjadi salah satu nilai dasar global. 10 [10] Kompetisi menjadi sebuah kata yang sangat sakti, siapa yang lebih kuat, siapa yang lebih siap, siapa yang kebih canggih, dan siapa yang besar modal dia akan memenangkan kompetisi. Kompetisi menjadi momok bagi pihak marginal baik secara kultural maupun struktural. Marginalisasi pihak-pihak yang tidak sepaham dengan agenda besar global telah mewujud secara transparan pada saat ini. Kelompok-kelompok marginal dengan modal "cekak," teknologi klasik, sumber daya manusia berkualitas rendah, dan jaringan sempit tidak akan mampu memberikan perlawanan berarti dalam kancah kompetisi global. Jangankan masyarakat bawah, para elit pemimpinnya pun masih tidak mampu memberikan perlawanan berarti. Inilah hakekat dari liberalisasi pendidikan.

Melihat demikian dahsyatnya gelombang liberalisasi sebagai nyawa dari paham liberalisme, maka lembaga pendidikan Islam di Indonesia harus mengantisipasinya dengan cara-cara demokratis dan elegan. Tantangan demi tantangan yang bersifat global harus dihadapi dan diselesaikan dengan arif dan bijaksana, tanpa kehilangan jati diri lembaga. Inilah yang menjadi inti dari kesiapan lembaga pendidikan Islam di Indonesia dalam menghadapi liberalisasi pendidikan, termasuk pesantren dan PTAI.

Secara yuridis pemerintah Indonesia telah menerima liberalisasi pendidikan.
Mulai dari bentuk kerja sama antara leṃinbaga pendidikan nasional dengan lembaga pendidikan asing, bahkan tidak lama lagi akan muncul lembaga pendidikan tinggi asing atau PTA di Indonesia. Untuk menghadapi tantangan liberalisasi pendidikan, maka pesantren dan PTAl perlu melakukan persiapan-persiapan khusus, di antaranya:

1. Memperkuat jati diri lembaga agàr tidak terjerumus ke jurang kesaláhan. Jati diri lembaga pendidikan dalam hal ini pesantren dan PTAI menjadi sangat penting untuk diperhatikan. Jati diri yang mudah tergerus oleh arus global hanya akan menyengsarakan umat Islam. Jati diri yang dimaksud di sini adalah orientasi utama pesantren dan PTAI. Berpegang teguh pada orientasi utama meniscayakan isù-isu global sebagai wacana yang tidak serta merta harus diikuti dan dilyakản, karena bagaimanapunjuga kehilangan orientasi hanya untuk mengejar kemajuan yang dicapai pihak lain hanyalah ilusi yang tidak mungkin tergapai. Prasyarat untuk mengejar kemajuan tersebut tidak akan pernah terpenuhi, karena hal ini sudah menyangkut perbedaan dasar ideologis, filosofis, bahkan nilai-nilai transendental. Pemaksaan terhadap adopsi nilai-nilai dasar dan penghilangan jati diri hanya akan menjadikan pengelola yang ada di dalamnya mengalami alienasi dari kultur masyarakat. Alih-alih akan melakukan perubahan pada masyarakat menjadi lebih maju, malah justru akan mengakibatkan munculnya manusia setengah-setengah. Setengah dirinya sendiri dan setengan orang lain. Model manusia setengah-setengah ini pada dasarnya telah melanda sebagian masyarakat Indonesia. Betapa tidak, sikap nasionalisme yang seharusnya 
dijunjung tinggi oieh semua pihak, justru sering dikalahkan kepentingan ekonomi sesaat yang hanya bermanfaat bagi seseorang atau sekelompok orang tertentu. Kenyataan yang seperti ini pada dasamya menjadi penyakit kronis negara-negara berkembang yang sebagian besar miskin. Bukan miskin dari kekayaan alam, akan tetapi beban hutang yang sangat berat, sehingga seakan-akan negara menjadi sangat miskin, padahal tidak. Karena ternyata di Indonesia banyak sekali orang-orang yang kaya luar biasa, meskipun sebagian besar masyarakatnya sangat miskin. Semua ini merupakan bukti bahwa kehilangan jati diri merupakan masalah yang serius untuk segera diatasi dengan penguatan jati diri melalui berbagai media dan sarana.

2. Memperkuat solidaritas sebagai warga bangsa. Solidaritas masyarakat Indonesia sebagai warga bangsa menjadi kekuatan luar biasa dalam menghadapi liberalisasi pendidikan. Solidaritas sebagai warga bangsa dapat diwujudkan dengan rasa bangga sebagai warga negara Indonesia, bangga dengan hasil karya warga bangsa sendiri, dan bangga bisa memberikan pengorbanan untuk kepentingan warga bangsa Indonesia. Solidaritas yang demikian ini, tidak akan muncul secara tiba-tiba, akan tetapi harus dipupuk sedemikian rupa dan dalam waktu yang panjang. Memberikan kepercayaan yang besar terhadap lembaga pendidikan sendiri merupakan wujud penguatan solidaritas warga bangsa. Untuk ini diperlukan perangkat yang memadai mulai dari dukungan finansial pemerintah, keseriusan pengelola lembaga pendidikan, keseriusan peserta didik, dan keseriusan dunia usaha dalam mengakomodasi output lembaga pendidikan nasional. Perwujudan solidaritas sesama warga bangsa menjadi isu sentral dalam menghadapi liberalisasi pendidikan, mengingat semakin memudarnya solidaritas warga. Pudarnya solidaritas sesama warga merupakan tragedi nasional yang harus segera dilakukan pertolongan dan pengentasan secara besar-besar. Kerusakan fisik akibat bencana alam, mungkin mampu diatasi dengan bantuan-bantuan dana dan kebutuhan pokok. Pudarnya solidaritas tidak akan mampu diatasi dengan bantuan dana, melainkan membutuhkan sosialisasi bahkan pendidikan yang cukup panjang dan ini jelas membutuhkan biaya ekstra yang luar biasa besar. Oleh karena itu, penguatan solidaritas warga bangsa menjadi sangat penting untuk dibudayakan dalam pesantren dan PTAl untuk menghadapi liberalisasi pendidikan.

3. Memperkuat kualitas diri. Pesantren dan PTAI selama ini dianggap sebagai lembaga pendidikan Islam yang tidak berkualitas, bila dibanding dengan lembaga pendidikan yang lain. Ketidakberkualitasannya terlihat dari kurangnya akomodasi dunia pesantren dan PTAl terhadap isu-isu global. Isuisu global yang kurang diakomodasi sebagian besar merupakan produk negara-negara maju yang nota bene berseberangan dengan mainstream keilmuan pesantren dan PTAI. Apalagi bila dilacak sampai pada dasar filosofi yang terkandung dalam isu-isu global tersebut, yang sebagian besar lebih cenderung pada pemujaan material daripada spiritual. Pandangan bahwa lembaga pendidikan Islam, khususnya pesantren tidak berkualitas perlu diklarifikasi lebih jauh. Sebab, bila 
dilihat lebih mendalam, khusus untuk pesantren justru kualitasnya telah teruji dengan masih eksisnya sampai saat ini. Betapa tidak, tantangan yang telah dihadapi pesantren sudah beraneka ragam dan datang dari mana saja, akan tetapi realitas membuktikan pesantren masih tetap eksis. Hal ini membuktikan bahwa tingkat survivalitas pesantren sangat tinggi. Pesantren oleh para pengelola dalam hal ini para ulama telah menemukan cara-cara yang elegan dan cantik untuk menghadapi berbagai tantangan. Diversivitas tantangan sejak zaman prakemerdekaan sampai saat ini sudah tidak dapat dihitung lagi banyaknya. Namun, semua tantangan dan sekaligus hambatan yang dihadapi pesantren dapat diatasi dengan baik dan mulus. Meskipun demikian, sebagai jawaban atas anggapan bahwa pesantren dan PTAI sebagai sebuah lembaga pendidikan yang dianggap kurang akomodatif, pengelola pesantren dan PTAI harus meningkatkan kualitas diri untuk tetap menjaga eksistensinya dalam rangka menghadapi liberalisasi pendidikan. Kualitas diri ini mencakuip kualitas înputi, súumber dayă manúsia, proses, layanan, lingküngan, dan output.11 [11] Dalam bahasa manajemen dikenal dengan sebutan quality assurance. Jaminan terhadap kủalitas seluruh' aspek tersebut 'menjadi tanggung jawab pengelola pesantren dan PTAl yang bersangkutan.

4. Memperkuat jaringan kerjasama.

- Jaringan kerjasamà (ñetworking) menjadi salah satu kekuatan sebuah lembaga pendidikan termasuk pesantren dan PTAl. Tanpa adanya jaringan kerjasama, pesantren dan PTAl tertentu akan terkucilkan dalam percaturan dunia akademik. Jaringan kejjasama ini bisa diwujudkan dalam bentuk jaringan formal dan informal. Dalam bentuk formal jaringan kerjasama dilakukan dengan instansi-instansi resmi pemerintah baik dalam maupun luar negeri dengan catatan harus tidak ada agenda terselubung dalam jaringan kerjasama tersebut. Jaringan kerjasama dalam bentuk informal dilakukan pesantren dan PTAl dengan lembaga swadaya masyarakat, organisasi sosial keagamaan, organisasi profesi, dan perusahaan-perusahaan yang bergerak di bidang industri. Sekali lagi kerjasama yang dibangun harus dilandaskan pada prinsip mutualisme, bukan bersifat ekspoitatif. Jaringan kerja sama di pesantren dan PTAl sebenarnya telah - terbentuk, akan tetapi masih perlu ditingkatkan kualitas dan.kuantitasnya dengan wilayah kerjasama:yang lebih luas dan bervariasi. Jaringan kejjasama yang sangat kuat di dunia pesantren adalah jaringan kerjasama-alumni. Jaringan alumni bukan hanya didasari atas kesadaran sebagai sesama almamater, akan tetapi terdapat ikatan spiritual yang tidak bisa diungkapkan

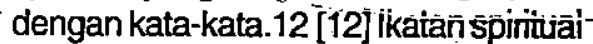
ini"bahkan menjadi ikatan kerjasama yang paling kuat. Ikatan jaringan alumni dengan kekuatan spiritual inilah yang selama ini tidak dimiliki oleh lembaga pendidikan lainnya. Oleh "karena itu, jaringan kejjasama antarálumnni menjadi sangat kuat di pesantren: Berbeda dengan jaringan alumni di PTAI yang kelihatan kurang berkembang dan - kurang solid, sehingga ikatan emosional - yang seharusnya ada dalam"sebuah -jaringan kurang menonjol. Inilah yang membedakan secara signifikan antara kekuatan jaringan pesantren' dan PTAI. 
5. Viemperkuas soliditas pengelola. Soliditas pergelola pesantren dan PTAI menjadi penentu utama dalam menghadapi liberaiisási pendiäikan. Soliditas pengeicla lemeaga pendiclikan micrupakan periyambung bagi kinerja lentbaga secara keseluruhan. Solidilas ini mencakup soliditas kinerja perencanaan, implementasi, dan evaluasi program peñuidikan yang diselenggarakan. itasing-masing pengelola telah rinemiliki cian menyaciari tugas, wewenang, keluasaan, tansgung ja:vab, dan rewarctiterteniu sesuai dengan jabatan dan furgsinya. Sinergisitas kinerja dari seluruh pengelola menjadi prasyarat terjalinn:ya soliditas pengelola. Semiua sasaran, kebijakan, program, dan kegiatan harus saling mengisi, bukan saling bertentangan atau bahkan saling menafikan. Suasana kerja juga menjadi penertu keserhasilan pencapaian tujuan dan sasaran yang ingin'dicapari. Semua ini menjadi tolok ukur bagi soliditas pengelola pesaritren dan PTAI: Tidak kalah pentingnyajuga bagi pesantren dan PTAl adalah meng-akomodasi dan membangun sikap familiar para pengelolanya terhadap sistem kinerja mutakhir. Sistem kinerja mutakhiri îni bisa berasal dari model pihak lain yang kemudian disinkro-nisasikan dengan tradisi sistem yang sudah ada. Sikap akomodatif 'dan familiar ini "merıjadi sangat diperlukan dalam bentuk penggunaan sarana dan prasarana berteknologi tinggi. Perkembangan sistem kinerja mutakhir, pada 'era sekarang ini memang kadang-kadang membingungkan. Namun, dengan memegang teguh nilai-nilai dasar yang menjadi tradisi sendiri, maka berbagai sistem kinerja-mutakhir tersebut dapat dijauikan sebagai wawasan pengem- bangan pengelolaan pesantreri cian PTA!. Pemantaatan sister: kinerja mutakhir ini tidak boleh mengakibatkan soloditas semakin merosot, bahkan se'jaliknya harus meningkatkan sinergisitas dari semua unit untuk memperkuat dan mening-katkan schiditas pengelola pesantren dan PTA.I. Semua ini merupakan keniscayaan bagi pesan!ren can PTAI dalam rangka menghaciap! liberalisasi pendidikan.

Semua persiapan yang tertera di aias tentu membutuhkan kesamaan visi dan orientasi dari semua pihak. Pihak-pihak yang dimaksud di sini ade!lah pihak interna! dan eksternal pesantren dan PTAI. Pihak internal meliputi semua civitas akademika pesantren dan PTAI, sedangikan pihak eksternal adalah umat Islam indonesia pada khususnya dan dunia Islam pada umumnya. Peringkatan hubungan mutualisme antara warga muslim satu negara dengan negara yang lain menjadi agenda utama dalam rangka menghadapi liberalisasi pendidikan yang menjadi isu global. Semúa negara akan menghadapi liberaiisasi pendidikan ini.

Persiapan-persiapan tersebut di atas hanyalah merupakan refleksi individual yang tidak mungkin mampu mengcover seluruh problematika dunia Islam, khususnya lembaga pendidikan Islam. Kompleksitas problematiká pếndidikan Islam dalam menghadapi liberalisasi pendidikan tidak akan mampu diselesaikan denǵan sébuah refleksi, akan tetapi harus dengan aksi yang konsisten dan massal. Namun demikian,

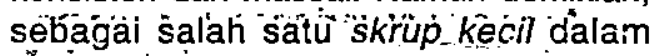
sebuah mesin sistem yang sangat besar (ṕêndídikań Iśläm),"penulis mencoba untuk melihat fênomèna yang adá berdasarkan realitas šejarah yang teläh berilarigsưung,

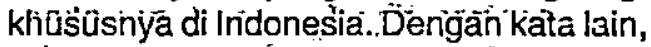
libēralisasi peńdidikan adalah́ sèbuah 
Pesantren dan Perguruan Tinggi.Agama Islam Menghadapi...; Ainurrafiq Dawam

realitas isu global yang sédang bergulir dan telah diratifikasi oleh sebagian besar negara, termasuik riegara-negara Islam, maka mau tidak mau atau suka tidak suka harus diliadaipi.

\section{Penut!!p}

Berdasarkan uraian di atas dapat dikatakan bahwa eksistensi pesantren sampai saat ini morupakan bukti bahwa pesantren telah mampu menghadapi berbagai tantangan dan hambatan yang senantiasa muncul pada zamannya. Sejak masa prakemerdekaan sampai saat ini tantangan dan hambatan yang dihadapi pesantren senantiasa berubah sesuai dengan perkembarigan masyarakat, ilmu pengetahuan, teknologi, dan seni. Sementara PTAI sebagai kelanjutan pesantren dalam hal tingkatan baru muncul pada masa kemerdekaan. PTAI itu sendiri pada dasarnya merupakan pesantren yang bernuansa akademis, karena PTAl selain memiliki ciri-ciri pesantren yakni sebagai lembagz dakwah dan juga ciri-ciri perguruan tinggi pada umumnya yâkni lembaga akademis dengan tri darmanya. Dengan kata lain PTAI merupakan integrasi dari dua lembaga yang harus mampu berjalan secara sinergis dan mutualis. Persiapan yang paling penting bagi kedua lembaga pendidikan Islam tersebut dalam menghadapi liberalisasi pendidikan adalah dengan penguatan dalam memegang teguh jati diri, penguatan solidaritas viarga negara, penguatan kualitas diri, penguatan jaringan kerjasama, dan penguatan soliditas pengèlöla. Dengan bekal nilai-nilai.dasar yang dimiliki, pesantren dan PTAI diharapkan mampu mempertahankan tradisi lama yang baik, mengambil tradisi baru yang lebih baik, dan menemukan tradisi mutakhir yang paling baik dalam istilah internasionalnya dikenal dengan "ai-muhafadzah 'ala al-qadim al-shalih, wa al-akhdzu bi al-jadid al-ashlah, wa al-ibda' bi al-muta'akhkhir ai-mumtaz." Wa Allah A'lam bi al-Shawab.

\section{Daftar Pustaka}

Assegaf, Abdurrahman, 2003, Intemasionalisasi Pendidikan: Sketsa Perbandingan PendidikandiNegara-negara Islamdan Barat, Yogyakarta: Gama Media, .

Depag, 2004,Data Statistik. Direktcrat Jenderal Kelembagaan Agama Islam, Jakarta: Depag.

Esyam, Asaat,1999, "Pembinaan dan Pengembangan .Pendidikan Agama dalam Menyongsong Era Globalisasi," dalam Fuaduddin \& Cik Hasan Easri, Dinamika Pemikiran Islam di Perguruan Tinggi: Wacana tentang Pendidikan Agama Islam, Jakarta: Logos Wacana limu.

Feisal, Jusuf Amir, 1995,Reorientasi Pendidikan Islam, Jakarta: Gema Insani Press.

Jalaluddin, 2002, Teologi Pendidikan, Jakarta: Raja Grafindo Persada.

Madjid, Nurcholish,1995, "Tasauf dan Pesantren," dalam M. Dawam Rahardjo, Pesantren dan Pembaharuan, Jakarta: L.P3ES.

Madjid, Nưrcholish,1997, Bilik-bilik Pesantren: Sebuah Potret Perjalanan, Jakarta: Paramadina.

Mastuhu,1939, Pemberdayaan Sistem Pendidikan Islam, Jakarta: Logos Wacana IImu. 
Topik: Globalisasi dan Liberalisasi dalam Bidang l'‘ndıJikan

Mubarok, Achmad,2005, Psikologi Keluarga: Dari Keluarga Sakinah Hingga Keluarga Bangsa, Jakarta: Bina Rena Pariwara dan IIIT Indonesia.

Shihab, M. Quraish, 1992, Membumikan al-

Qur’an: Fungsi dán Peranan Wahyu

dalam kehidupan Masyarakat, - Bandung: Mizañ.

Zamroni,2000, Paradigma Pendidikan Masa Depan, Yogyakarta: Bigraf Publishing. 